\title{
PEMODELAN KASUS GIZI BURUK PADA BALITA DI PROVINSI BALI TAHUN 2018 MENGGUNAKAN REGRESI SPLINE
}

\author{
Nyoman Krishna Pratiwi Dangin ${ }^{1 \S}$, I Gusti Ayu Made Srinadi², I Wayan Sumarjaya ${ }^{3}$ \\ ${ }^{1}$ Prodi Matematika, Fakultas MIPA - Universitas Uday ana [Email: krishnapratiwi1399@gmail.com] \\ ${ }^{2}$ Prodi Matematika, Fakultas MIPA - Universitas Uday ana [Email: srinadi@ unud.ac.id] \\ ${ }^{3}$ Prodi Matematika, Fakultas MIPA - Universitas Udayana [Email: sumarjaya@ unud.ac.id] \\ ${ }^{\S}$ Corresponding Author
}

\begin{abstract}
Malnutrition associated with an unusual condition of the patient's nutritional status because the body weight index and age are not suitable, where body weight should be positively correlated with age. According to data from the Bali Health Department, malnutrition cases found in 2016 is 3,4\% while in 2017 it founded 3,8\%. This research uses spIine regression with malnutrition cases of children under 5 years old in Bali Province. To compare basis truncated spIine and B-SpIine, this study using the minimum value of Generalized Cross Validation (GCV) and Mean Square Error (MSE) of each basis. $B$-SpIine quadratic modeI with four knots is the best model.
\end{abstract}

Keywords: Malnutrition, Generalized Cross Validation (GCV), Knots, Truncated SpIine, B-SpIine.

\section{PENDAHULUAN}

Sebagai salah satu cara untuk memandang hubungan kausalitas antara variabel respons dengan variabel prediktor, analisis regresi dalam implementasinya memiliki tiga pendekatan yang kerap digunakan untuk menduga kurva regresi. Pendekatan dalam analisis regresi ialah pendekatan parametrik, semiparametrik, dan nonparametrik.

Pendekatan parametrik baik dipakai bilamana bentuk kurva regresi diketahui, bila terdapat pergerakan dari data yang tidak diharapkan maka pendekatan parametrik kurang mampu memodelkan hubungan variabel respons dan variabel prediktor dengan baik, perihal ini menjadi salah satu kelemahan pendekatan parametrik. Bilamana kurva regresi yang dibangun memuat komponen parametrik dan komponen nonparametrik maka pendekatan semiparametrik dapat dipakai. Pendekatan nonparametrik menjadi alternatif bila tidak terdapat informasi terkait bentuk kurva regresi (Eubank, 1999). Salah satu teknik estimasi kurva regresi dalam regresi nonparametrik yang kerap dipakai adalah regresi spline.

Regresi spline adalah analisis regresi yang memakai pendekatan ke arah plot data. Regresi spline mempunyai titik-titik yang menghubungkan antar kurva yang disebut titik knot. Basis fungsi dalam memodelkan regresi nonparametrik spline antara lain adalah truncated spline serta B-Spline (Lyche \& Mørken, 2008).

Dibandingkan dengan model polinomial lain, basis fungsi truncated spline ialah model polinomial yang mempunyai fleksibilitas yang lebih tinggi karena menghasilkan fungsi regresi yang sesuai dengan data. Pemilihan orde dan titik knot disesuaikan berdasarkan data di mana apabila orde yang akan diujikan tinggi maka basis $B$-Spline dapat menjadi alternatif. Basis $B$ spline digunakan dalam mengatasi model spline saat orde tinggi dan titik knot yang banyak. Basis $B$-Spline hanya dapat didefinisikan secara rekursif dan karenanya tidak dapat dievaluasi secara langsung.

Pemodelan yang dilakukan Anggreni, dkk. (2018) terkait persoalan tuberkulosis di Provinsi Bali memakai regresi nonparametrik truncated spIine dengan variabel prediktor persentase rumah tangga sikap hidup bersih serta sehat, persentase kepadatan penduduk, persentase tempat umum sehat, persentase tempat pengolahan makanan sehat, persentase umur produktif serta persentase tenaga kesehatan terlatih, digapai model terbaik yakni orde 2 dengan 1 titik knot dan koefisien determinasi sejumlah $70,48 \%$. Riset lain dilakukan oleh 
Rahmaw ati, dkk. (2017) yang memakai basis $B$ Spline dalam memodelkan persoalan kemiskinan di Jawa tengah dengan variabel respons persentase penghuni miskin serta variabel prediktor ialah laju pengekspansian ekonomi, tingkat pengangguran terbuka (TPT), tingkat pembelajaran SMA ke atas, dalam riset ini digapai basis $B$ - Spline dengan orde 2 ialah model dengan GCV terendah serta koefisien determinasi sejumlah $67,79 \%$ yang bermakna ketiga variabel prediktor tertera memengaruhi persentase penghuni miskin sejumlah $67,79 \%$.

Gizi buruk dikaitkan dengan sesuatu keadaan status gizi pengidap yang tidak umum di mana indeks berat tubuh serta usia tidakcocok dengan pengidap, di mana wajarnya berat tubuh berkorelasi positif dengan usia. Perolehan pemantauan status gizi (PSG) tahun 2016 menampakkan besaran bayi gizi buruk sejumlah 3, 4\%, sebaliknya tahun 2017 PSG menampakkan besaran sejumlah 3,8\%. Hal ini menunjukkan nilai yang tidak jauh berbeda masing-masing tahun. Perolehan ini mengindikasikan upaya pembangunan yang dilakukan pemerintah belum optimal.

Dengan menerapkan regresi nonparametrik spline pada kurva regresi yang tidak diketahui akan mampu membangun model dengan baik. Berkaitan dengan itu, peneliti mencoba memodelkan persentase gizi buruk dengan basis Truncated dan B-Spline.

Asumsi-asumsi yang mendasari regresi parametrik tidak berlaku pada pendekatan nonparametrik serta pendekatan nonparametrik mempunyai fleksibilitas lebih besar, diharapkan data mencari taksiran kurva regresinya sendiri (Eubank, 1999). Secara universal ikatan $X$ serta $Y$ dengan $n$ pengamatan diuraikan :

$$
y_{i}=f\left(x_{i}\right)+\varepsilon_{i} \quad, i=1,2,3, \ldots, n
$$

dengan $y_{i}$ selaku variabe 1 respons, $f$ ialah kurva regresi yang diasumsikan tidak diketahui bentuknya, $x_{i}$ selaku variabel prediktor, sedangkan $\varepsilon_{i}$ ialah residual yang diasumsikan bebas dngan mean serta varians $\sigma^{2}$.

Dalam fungsi spline ada titik-titik penghubung yang disebut titik knot. Secara universal model regresi spline dengan satu variabel respons serta variabel prediktor atas suatu fungsi dengan orde $m$ bisa dikemukakan sebagai berikut (Eubank, 1999):

$$
f\left(x_{i}\right)=\sum_{r=0}^{m-1} \beta_{r} x_{i}^{r} \sum_{p=1}^{l} \beta_{(m-1+p)}\left(x_{i}-k_{p}\right)_{+}^{m-1}
$$

dengan $\beta_{0}, \beta_{1}, \beta_{2}, \cdots, \beta_{m-1}, \beta_{(m-1+p)} \quad$ ialah koefisien regresi, $x_{i}^{1}, x_{i}^{2}, \cdots x_{i}^{m-1}$ ialah satu variabe1 prediktor yang nilainya diketahui, sedangkan $\left(x_{i}-k_{p}\right)_{+}^{m-1}$ ialah fungsi truncated yang dapat dijabarkan seperti berikut:

$$
\begin{aligned}
& \left(x_{i}-k_{p}\right)^{m-1}= \\
& \left\{\begin{array}{cl}
\left(x_{i}-k_{p}\right)^{m-1} & , x_{i} \geq k_{p} \\
0 & , x_{i}<k_{p}
\end{array} .\right.
\end{aligned}
$$

persamaan regresi nonparametrik truncated spIine selanjutnya didefinisikan sebagai berikut:

$$
\begin{gathered}
y_{i}=\sum_{r=0}^{m-1} \beta_{r} x_{i}^{r}+\sum_{\substack{p=1 \\
+\varepsilon_{i}}}^{l} \beta_{(m-1+p)}\left(x_{i}-k_{p}\right)_{+}^{m-1} \\
, i=1,2,3, \ldots, n .
\end{gathered}
$$

Maximum likelihood estimator (MLE) dipakai selaku estimasi regresi nonparametrik spIine. Bila galat diasumsikan bersebaran normal pada persamaan (2.1), maka $y_{i}$ juga bersebaran normal dengan nilai tengah $f\left(x_{i}\right)$ serta varians $\sigma^{2}$. Sehingga fungsi densitas peluang $y_{i}$ sebgai berikut:

$$
\begin{gathered}
f\left(y ; f(x), \sigma^{2}\right)=\frac{1}{\sqrt{2 \pi \sigma^{2}}} \exp \left[-\frac{(y-f(x))^{2}}{2 \sigma^{2}}\right] \\
, f(x)>0, \sigma^{2}>0 .
\end{gathered}
$$

Fungsi likelihood dapat dikemukakan seperti berikut :

$$
\begin{aligned}
L(y, f)= & \prod_{i=1}^{n} f\left(y ; f(x), \sigma^{2}\right) \\
= & \left(2 \pi \sigma^{2}\right)^{-\frac{n}{2}} \exp \left[-\frac{1}{2 \sigma^{2}} \sum_{i=1}^{n}\left[y_{i}-\right.\right. \\
& \left.\left.f\left(x_{i}\right)\right]^{2}\right] .
\end{aligned}
$$

Estimator titik $f$ diperoleh dengan memaksimumkan fungsi likelihood $L(y, f)$ berikut :

$$
\begin{aligned}
& \left.\max _{2 L}(y, f)\right\}= \\
& \max _{\beta \in R^{m+r}}\left\{( 2 \pi \sigma ^ { 2 } ) ^ { - \frac { n } { 2 } } \operatorname { e x p } \left[-\frac{1}{2 \sigma^{2}} \sum_{i=1}^{n}\left[y_{i}-\right.\right.\right. \\
& \left(\sum_{r=0}^{m-1} \beta_{r} x_{i}^{r}+\sum_{p=1}^{l} \beta_{(m-1+p)}\left(x_{i}-\right.\right. \\
& \left.\left.\left.\left.\left.k_{p}\right)_{+}^{m-1}\right)\right]^{2}\right]\right\}
\end{aligned}
$$

Selanjutnya dilakukan transformasi logaritma terhadap persamaan (2.6) kemudian perolehan transformasi logaritma tersebut diturunkan secara parsial terhadap $\beta$ dan disamakan dengan nol, sampai-sampai didapat : 


$$
\hat{\beta}=\left(x^{\prime} x\right)^{-1} x^{\prime} y .
$$

Estimasi $\hat{y}$ dapat dikemukakan seperti berikut:

$$
\hat{y}=x\left(x^{\prime} x\right)^{-1} x^{\prime} y=A(k) y
$$

dengan $A(k)$ ialah matriks yang dipakai untuk menghitung nilai GCV dalam pemilihan knot.

Bilamana persamaan (2.1) didekati dengan fungsi $B$-spline orde $m$ dengan $k$ knot, persamaan bisa diuraikan sebagai berikut (Eubank, 1999):

$$
y_{i}=\sum_{l=1}^{m+k} \alpha_{l} N_{l-m, m}\left(x_{i}\right)+\varepsilon_{i}, i=1,2, \ldots, n
$$

dengan $N_{l-m, m}$ ialah basis $B$-spline dan $\alpha_{l}$ menjadi parameter regresi untuk $B$ - spline. Dalam membangun fungsi $B$ - spline dengan orde $m$ dan titik knot $a<\xi_{1}<\xi_{2}<\cdots<\xi_{k}<$ $b$ 1ebih dulu menafsirkan knot tambahan sejumlah $2 m, \quad$ yakni $\xi_{-(m-1)}, \cdots, \xi_{-1}, \xi_{0}, \xi_{k+1}, \cdots, \xi_{k+m}$ dengan $\xi_{-(m-1)}=\cdots=\xi_{0}=a \quad$ dan $\quad \xi_{(k+1)}=\cdots=$ $\xi_{k+m}=b$. Lazimnya $a$ diambil dari nilai minimum $x$ dan $b$ diambil dari nil ai maksimum $x$. B-spline dengan orde $m$ serta titik knot $\xi_{1}, \xi_{2}, \cdots, \xi_{k}$ dapat ditafsirkan secara rekursif seperti berikut :

$$
\begin{aligned}
N_{l, m}(x)= & \frac{x-\xi_{l}}{\xi_{l+m-1}-\xi_{l}} N_{l, m-1}(x)+ \\
& \frac{\xi_{l+m}-x}{\xi_{l+m}-\xi_{l+1}} N_{l+1, m-1}(x)
\end{aligned}
$$

dengan $l=-(m-1), \cdots, k$

$$
N_{l, 1}(x)=\left\{\begin{array}{lr}
1, & x \in\left(\xi_{i}, \xi_{i+1}\right) \\
0, & \text { lainnya. }
\end{array}\right.
$$

Untuk estimasi koefisien $\alpha$ atas persamaan (2.9), ditafsirkan matriks $N(\lambda)$ berukuran $n \times$ $(m+K)$ (Budiantara dkk., 2006)

$$
N(\lambda)=\left[\begin{array}{cccc}
N_{1-m, m}\left(x_{1}\right) & N_{2-m, m}\left(x_{1}\right) & \cdots & N_{K, m}\left(x_{1}\right) \\
N_{1-m, m}\left(x_{2}\right) & N_{2-m, m}\left(x_{2}\right) & \cdots & N_{K, m}\left(x_{2}\right) \\
\vdots & \vdots & & \vdots \\
N_{1-m, m}\left(x_{n}\right) & N_{2-m, m}\left(x_{n}\right) & \cdots & N_{K, m}\left(x_{n}\right)
\end{array}\right]
$$

Metode least squares spline digunakan dalam menduga parameter $\alpha_{\lambda}$. Jumlah kuadrat error ataupun residual sum of squares (RSS) diminimumkan untuk memperoleh estimator

$$
\widehat{\alpha_{\lambda}} \text { : }
$$

$$
\widehat{\alpha_{\lambda}}=\left(N_{\lambda}^{T} N_{\lambda}\right)^{-1} N_{\lambda}^{T} y
$$

Estimasi model $B$-spline atas regresi nonparametrik ialah:

$$
\hat{y}=N_{\lambda}\left(N_{\lambda}^{T} N_{\lambda}\right)^{-1} N_{\lambda}^{T} y=S_{\lambda} y
$$

Pemilihan titik knot optimal dicoba untuk memperoleh suatu model regresi spline terbaik. Pemilihan titik knot yang optimal dapat memakai kriteria GCV (Eubank, 1999).

$$
G C V(k)=\frac{M S E(k)}{\left(n^{-1} \operatorname{tr}[I-A(k)]\right)^{2}}
$$

Fungsi (2. 12) dipakai untuk memeroleh nilai GCV fungsi truncated spline dengan $\operatorname{MSE}(k)=n^{-1} \sum_{i=1}^{n}\left(y_{i}-\hat{y}\right)^{2}$. Sedangkan untuk memperoleh nilai GCV pada fungsi $B$ spline ditafsirkan seperti berikut :

$$
\operatorname{GCV}(\lambda)=\frac{\operatorname{MSE}(\lambda)}{\left(n^{-1} \operatorname{tr}\left[I-S_{\lambda}\right]\right)^{2}}
$$

Pemilihan model terbaik dicoba dengan memilah nilai GCV serta MSE yang paling minimum.

\section{METODE PENELITIAN}

\subsection{Jenis dan Sumber Data}

Pemodelan jumlah gizi buruk pada balita di Provinsi Bali memakai jenis data sekunder. Data yang dipakai ialah data dari 57 kecamatan di Provinsi Bali tahun 2018 yang diperoleh dari Dinas Kesehatan Provinsi Bali.

\subsection{Variabel Penelitian}

Variabel respons dalam penelitian ini ialah jumlah balita penderita gizi buruk di Provinsi Bali tahun 2018. Terdapat enam variabel prediktor yang dipakai yaitu Persentase bayi baru lahir mendapat ASI eksk1usif sampai usia 6 bulan $\left(X_{1}\right)$, Persentase berat bayi lahir rendah (BBLR) $\left(X_{2}\right)$, Persentase posyandu aktif $\left(X_{3}\right)$, persentase tempat pengolahan makanan (TPM) memenuhi syarat kesehatan $\left(X_{4}\right)$, persentase ibu hamil mendapatkan tablet tambah darah (TTD) $\left(X_{5}\right)$, persentase balita umur $6-59$ bulan mendapat vitamin $\mathrm{A}\left(X_{6}\right)$.

\subsection{Metode Analisa Data}

Teknik analisis data dilakukan dengan regresi nonparametrik truncated spline dan $B$ Spline dan dengan bantuan software R. Ada pula tahapan yang dicoba ialah selaku berikut:

1. Memilih titik knot optimal untuk basis truncated spIine dengan tahapan seperti berikut :

a. Memutuskan $m$ orde dan $k$ titik knot 
b. Menggali matriks $A(k)$ yang memenuhi persamaan (2.8)

c. Memilih nilai GCV minimum untuk memutuskan titik knot optima1 sesuai dengan persamaan (2.12)

2. Memilih titik knot optimal untuk basis $B$ SpIine dengan tahapan sepertiberikut :

a. Membuat basis fungsi $B$-spline pada $m$ orde serta $k$ titik knot sesuai persamaan (2.10)

b. Menggali matriks $S_{\lambda}$ yang memenuhi persamaan (2.11)

c. Menggali titik knot optimal dengan memilih nilai GCV yang paling minimun sesuai persamaan (2.13)

3. Memilih basis terbaik antara truncated spline dan $B$-Spline dengan melihat nilai GCV minimum serta nilai koefisien determinasi $\left(R^{2}\right)$ terbesar.

4. Memodelkan regresi nonparametrik dengan basis serta titik knot terpilih

5. Menginterpretasikan model yang terpilih serta menarik kesimpulan.

\section{HASIL DAN PEMBAHASAN}

\subsection{Pemilihan Titik Knot Optimal atas Regresi Nonparametrik Truncated Spline}

Pemilihan titik knot optimal dilakukan dengan memilih nilai GCV paling minimum dengan bantuan software R x64 4.0.3. Pemilihan titik knot optimal pada penelitian ini dibatasi dari satu titik knot sampai empat titik knot pada spline truncated linier (orde 2), dan kuadratik (orde 3). Selanjutnya diuraikan nilai GCV minimum pada masing-masing orde dan titik knot seperti berikut:

Tabel 1. Tabel Nilai GCV dari Masing-masing Orde dan Titik Knot

\begin{tabular}{|c|c|c|}
\hline Orde & Banyak Titik Knot & GCV \\
\hline \multirow{3}{*}{ Orde } & 1 Titik Knot & 6,42599 \\
\cline { 2 - 3 } 2 & 2 Titik Knot & $\mathbf{6 , 3 8 8 0 4}$ \\
\cline { 2 - 3 } & 3 Titik Knot & 6,49157 \\
\cline { 2 - 3 } & 4 Titik Knot & 6,60559 \\
\hline \multirow{3}{*}{ Orde } & 1 Titik Knot & 6,54434 \\
\cline { 2 - 3 } 3 & 2 Titik Knot & 6,50479 \\
\cline { 2 - 3 } & 3 Titik Knot & 7,08386 \\
\cline { 2 - 3 } & 4 Titik Knot & 7,94239 \\
\hline
\end{tabular}

Berdasarkan Tabel 4.2 pemodelan truncated spline pada orde 2 dengan 2 titik knot memiliki nilai GCV paling minimum yaitu 6,38804 , nilai MSE sebesar 1,904357 serta nilai koefisien determinasi sebesar 0,6189174 dengan titik knot optimal berturut-turut terletak pada titik $X_{1}=$ 51,72 dan 58,43; $X_{2}=1,69$ dan 2,52; $X_{3}=$ 42,61 dan 50; $X_{4}=22,39$ dan 34,95; $X_{5}=$ 87,48 dan 91,47; dan $X_{6}=97,14$ dan 97,83.

\subsection{Pemilihan Titik Knot Optimal pada Regresi Nonparametrik B-Spline}

Pemilihan titik knot yang optimal dalam penelitian ini, hanya dibatasi pada satu knot, dua knot, tiga knot, dan empat knot pada B-spline linier (orde 2) dan kuadratik (orde 3) dengan kriteria nilai GCV yang paling minimum. Berikut merupakan nilai GCV minimum untuk masing-masing orde dan titik knot:

Tabel 2. Tabel Nilai GCV dari Masing-masing Orde dan Titik Knot

\begin{tabular}{|c|c|c|}
\hline Orde & Banyak Titik Knot & GCV \\
\hline \multirow{3}{*}{ Orde } & 1 Titik Knot & 6,413497 \\
\cline { 2 - 3 } 2 & 2 Titik Knot & 6,363895 \\
\cline { 2 - 3 } & 3 Titik Knot & 6,311757 \\
\cline { 2 - 3 } & 4 Titik Knot & 6,54205 \\
\hline \multirow{3}{*}{ Orde } & 1 Titik Knot & 6,46338 \\
\cline { 2 - 3 } 3 & 2 Titik Knot & 6,28425 \\
\cline { 2 - 3 } & 3 Titik Knot & 6,28557 \\
\cline { 2 - 3 } & 4 Titik Knot & $\mathbf{6 , 2 7 8 7 5}$ \\
\hline
\end{tabular}

Nilai GCV paling minimum yaitu pada orde 3 dengan 4 titik knot yaitu 6,27875 dan nilai MSE sebesar 0,8669923 dengan titik knot optimal berturut-turut terletak pada titik 51,$72 ; 58,43$; 69,$93 ; 71,33 ; 1,69 ; 2,52 ; 3,61 ; 3,81 ; 42,61 ; 50$; 62,$19 ; 66,28 ; 22,39 ; 34,95 ; 73,37 ; 78,9 ; 87,48$; 91,$47 ; 95,07 ; 96,16 ; 97,14 ; 97,83 ; 99,47$; dan 99,49 , dengan koefisien determinasi $R^{2}=$ 0,8265054 . Estimasi model yang diperoleh adalah sebagai berikut :

$$
\begin{aligned}
\hat{Y}_{l}= & 5,63-5,25 N_{-2,3}\left(X_{1}\right)-8,55 N_{-1,3}\left(X_{1}\right)- \\
& 11,8 N_{0,3}\left(X_{1}\right)-7,7 N_{1,3}\left(X_{1}\right)- \\
& 13,07 N_{2,3}\left(X_{1}\right)-14,78 N_{3,3}\left(X_{1}\right)- \\
& 9,05 N_{4,3}\left(X_{1}\right)+2,18 N_{-2,3}\left(X_{2}\right)- \\
& 1,63 N_{-1,3}\left(X_{2}\right)+2,61 N_{0,3}\left(X_{2}\right)+ \\
& 4,31 N_{1,3}\left(X_{2}\right)+0,09 N_{2,3}\left(X_{2}\right)+ \\
& 2,09 N_{3,3}\left(X_{2}\right)+4,04 N_{4,3}\left(X_{2}\right)+ \\
& 2,21 N_{-2,3}\left(X_{3}\right)-0,44 N_{-1,3}\left(X_{3}\right)- \\
& 0,64 N_{0,3}\left(X_{3}\right)-0,08 N_{1,3}\left(X_{3}\right)- \\
& 4,57 N_{2,3}\left(X_{3}\right)+10,56 N_{3,3}\left(X_{3}\right)- \\
& 2,06 N_{4,3}\left(X_{3}\right)+6,96 N_{-2,3}\left(X_{4}\right)+ \\
& 2,28 N_{-1,3}\left(X_{4}\right)+3,01 N_{0,3}\left(X_{4}\right)+ \\
& 1,79 N_{1,3}\left(X_{4}\right)+3,07 N_{2,3}\left(X_{4}\right)+ \\
& 4,72 N_{3,3}\left(X_{4}\right)+1,2 N_{4,3}\left(X_{4}\right)+ \\
& 6,82 N_{-2,3}\left(X_{5}\right)-2,27 N_{-1,3}\left(X_{5}\right)+
\end{aligned}
$$




$$
\begin{aligned}
& 3,15 N_{0,3}\left(X_{5}\right)+4,01 N_{1,3}\left(X_{5}\right)+ \\
& 1,83 N_{2,3}\left(X_{5}\right)+4,75 N_{3,3}\left(X_{5}\right)+ \\
& 2,77 N_{4,3}\left(X_{5}\right)+1,91 N_{-2,3}\left(X_{6}\right)+ \\
& 1,54 N_{-1,3}\left(X_{6}\right)+2,4 N_{0,3}\left(X_{6}\right)- \\
& 3,06 N_{1,3}\left(X_{6}\right)-1,55 N_{2,3}\left(X_{6}\right)+ \\
& 4,18 N_{3,3}\left(X_{6}\right)-0,66 N_{4,3}\left(X_{6}\right) .
\end{aligned}
$$

\subsection{Interpretasi Model Terpilih}

Berdasarkan nilai MSE dan $R^{2}$ basis Truncated Spline dan $B$-spline dapat disimpulkan bahwa estimasi model terbaik merupakan model dengan basis $B$-spline. Interpretasi dari model terbaik regresi nonparametrik $B$-Spline dilakukan dengan mempertimbangkan rentangan serta nilai dari basis $B$-Spline masing-masing variabel prediktor yang telah diperoleh. Interpretasi dari model yang terpilih dapat diuraikan sebagai berikut :

1. Apabila variabel $X_{2}, X_{3}, X_{4}, X_{5}, X_{6}$ diasumsikan tetap, pengaruh persentase bayi baru lahir mendapat ASI eksklusif $\left(X_{1}\right)$ terhadap jumlah balita penderita gizi buruk pada kecamatan ke- $i$ di Provinsi Bali $\left(Y_{i}\right)$ dapat dinyatakan sebagai berikut:

$\hat{Y}_{i}=5,63-5,25 N_{-2,3}\left(X_{1}\right)$

dengan

$$
\begin{aligned}
& N_{-2,3}\left(X_{1}\right) \\
& =\left\{\begin{array}{cc}
\left(\frac{51,72-X_{1}}{10,93}\right), & 40,79 \leq X_{1}<51,72^{2} \\
0 & , 51,72 \leq X_{1}<58,43 \\
0 & , 58,43 \leq X_{1}<69,93 \\
0 & , \quad 69,93 \leq X_{1}<71,33 \\
0 & , 71,33 \leq X_{1}<86,78 \\
0 & \text { untuk } X_{1} \text { lainnya }
\end{array}\right.
\end{aligned}
$$$$
\widehat{Y}_{i}=5,63-9,05 N_{4,3}\left(X_{1}\right)
$$

dengan

$$
\begin{aligned}
& N_{4,3}\left(X_{1}\right) \\
& =\left\{\begin{array}{cl}
\left(\frac{X_{1}-71,33}{15,43}\right)^{2}, & 71,33 \leq X_{1}<86,78 \\
0 & , \text { untuk } X_{1} \text { lainnya }
\end{array}\right.
\end{aligned}
$$

Saat persentase bernilai minimum yaitu 40,79\% disubstitusi ke persamaan (4.1), diperoleh jumlah balita penderita gizi buruk berkurang 5 kasus. Apabila persentase maksimum $86,78 \%$ disubstitusi ke persamaan (4.2), diperoleh kasus balita penderita gizi buruk akan berkurang sebanyak 9 kasus. Peningkatan persentase bayi baru lahir mendapat ASI eksklusif akan menurunkan jumlah kasus balita penderita gizi buruk di Provinsi Bali.

2. Apabila variabel $X_{1}, X_{3}, X_{4}, X_{5}, X_{6}$ diasumsikan tetap, pengaruh persentase berat bayi lahir rendah (BBLR) $\left(X_{2}\right)$ terhadap jumlah balita penderita gizi buruk pada kecamatan ke- $i$ di Provinsi Bali $\left(Y_{i}\right)$ adalah sebagai berikut:

$$
\hat{Y}_{i}=5,63+2,18 N_{-2,3}\left(X_{2}\right)
$$

dengan

$$
N_{-2,3}\left(X_{2}\right)= \begin{cases}\left(\frac{1,69-X_{2}}{1,58}\right)^{2} & , 0,11 \leq X_{2}<1,69 \\ 0 & , 1,69 \leq X_{2}<2,52 \\ 0 & , 2,52 \leq X_{2}<3,61 \\ 0 & , 3,61 \leq X_{2}<3,81 \\ 0 & , 3,81 \leq X_{2}<6,28 \\ 0 & , \text { untuk } X_{2} \text { lainnya }\end{cases}
$$

$$
\hat{Y}_{i}=5,63+4,04 N_{4,3}\left(X_{2}\right)
$$

dengan

$$
\begin{aligned}
& N_{4,3}\left(X_{2}\right) \\
& =\left\{\begin{array}{c}
\left(\frac{X_{2}-3,81}{2,47}\right)^{2}, 3,81 \leq X_{2}<6,28 \\
0, \text { untuk } X_{2} \text { lainnya }
\end{array}\right.
\end{aligned}
$$

Ketika persentase minimum $0,11 \%$ dan disubstitusi ke persamaan (4.3), diperoleh jumlah balita penderita gizi buruk bertambah sebanyak 2 kasus. Apabila persentase maksimum 6,28\% disubstitusi ke persamaan (4.4), maka ditemukan kasus balita penderita gizi buruk bertambah sebanyak 4 kasus. Peningkatan persentase BBLR akan meningkatkan jumlah kasus balita penderita gizi buruk di Provinsi Bali.

3. Apabila variabel $X_{1}, X_{2}, X_{4}, X_{5}, X_{6}$ diasumsikan tetap, maka pengaruh persentase posyandu aktif $\left(X_{3}\right)$ terhadap jumlah balita penderita gizi buruk pada kecamatan ke- $i$ di Provinsi Bali $\left(Y_{i}\right)$ adalah sebagai berikut:

$$
\begin{aligned}
& \hat{Y}_{i}=5,63+2,21 N_{-2,3}\left(X_{3}\right) \\
& \text { dengan }
\end{aligned}
$$

$$
N_{-2,3}\left(X_{3}\right)
$$




$$
\begin{aligned}
& = \\
& \begin{cases}\left(\frac{42,61-X_{3}}{42,61}\right)^{2} & , 0 \leq X_{3}<42,61 \\
0 & , 42,61 \leq X_{3}<50 \\
0 & , 50 \leq X_{3}<62,19 \\
0 & , 62,19 \leq X_{3}<66,28 \\
0 & , 66,28 \leq X_{3}<100 \\
0 & , \text { untuk } X_{3} \text { lainnya }\end{cases}
\end{aligned}
$$

$\hat{Y}_{i}=5,63-2,06 N_{4,3}\left(X_{3}\right)$

dengan

$$
\begin{aligned}
& N_{4,3}\left(X_{3}\right) \\
& =\left\{\begin{array}{cl}
\left(\frac{X_{3}-66,28}{33,72}\right)^{2}, & , 66,28 \leq X_{3}<100 \\
0, & \text { untuk } X_{3} \text { lainnya }
\end{array}\right.
\end{aligned}
$$

Ketika persentase posyandu aktif bernilai minimum yaitu $0 \%$ dan disubstitusi ke persamaan (4.5), diperoleh jumlah balita penderita gizi buruk bertambah sebanyak 2 kasus. Selanjutnya apabila persentase maksimum yaitu $100 \%$ disubstitusi ke persamaan (4.6), diperoleh kasus balita penderita gizi buruk berkurang sebanyak 2 kasus. Peningkatan persentase posyandu aktif akan menurunkan jumlah kasus balita penderita gizi buruk di Provinsi Bali.

4. Apabila variabel $X_{1}, X_{2}, X_{3}, X_{5}, X_{6}$ diasumsikan tetap, maka pengaruh persentase tempat pengolahan makanan (TPM) $\left(X_{4}\right)$ terhadap jumlah balita penderita gizi buruk pada kecamatan ke- $i$ di Provinsi Bali $\left(Y_{i}\right)$ adalah sebagai berikut:

$\widehat{Y}_{i}=5,63+6,96 N_{-2,3}\left(X_{4}\right)$

dengan

$$
\begin{aligned}
& N_{-2,3}\left(X_{4}\right) \\
& = \begin{cases}\left(\frac{22,39-X_{4}}{20,61}\right)^{2} & , 1,78 \leq X_{4}<22,39 \\
0 & , 22,39 \leq X_{4}<34,95 \\
0 & , 34,95 \leq X_{4}<73,37 \\
0 & , 73,37 \leq X_{4}<78,9 \\
0 & , 78,9 \leq X_{4}<100 \\
0 & , \text { untuk } X_{4} \text { lainnya }\end{cases} \\
& \hat{Y}_{i}=5,63+1,2 N_{4,3}\left(X_{4}\right) \\
& \text { dengan }
\end{aligned}
$$

$$
\begin{aligned}
& N_{4,3}\left(X_{4}\right) \\
& = \begin{cases}\left(\frac{X_{4}-78,9}{21,1}\right)^{2}, & 78,9 \leq X_{4}<100 \\
0 \quad, \text { untuk } X_{4} \text { lainnya }\end{cases}
\end{aligned}
$$

Ketika persentase TPM memenuhi syarat kesehatan bernilai minimum 1,78\% dan disubstitusikan ke persamaan (4.7), diperoleh jumlah balita penderita gizi buruk di kecamatan tersebut bertambah sebanyak 7 kasus. Apabila persentase maksimum 100\%, nilai tersebut disubstitusi ke persamaan (4.8) diperoleh kasus balita penderita gizi buruk berkurang sebanyak 1 kasus. Peningkatan persentase TPM akan menurunkan jumlah kasus balita penderita gizi buruk di Provinsi Bali.

5. Apabila variabel $X_{1}, X_{2}, X_{3}, X_{4}, X_{6}$ diasumsikan tetap, maka jumlah balita penderita gizi buruk pada kecamatan ke- $i$ di Provinsi Bali $\left(Y_{i}\right)$ yang dipengaruhi persentase ibu hamil mendapat tablet tambah darah (TTD) $\left(X_{5}\right)$ adalah sebagai berikut:

$\hat{Y}_{i}=5,63+6,82 N_{-2,3}\left(X_{5}\right)$

dengan

$$
\begin{aligned}
& N_{-2,3}\left(X_{5}\right) \\
& = \begin{cases}\left(\frac{87,48-X_{5}}{19,39}\right)^{2} & , 68,09 \leq X_{5}<87,48 \\
0 & , 87,48 \leq X_{5}<91,47 \\
0 & , 91,47 \leq X_{5}<95,07 \\
0 & , 95,07 \leq X_{5}<96,16 \\
0 & , 96,16 \leq X_{5}<109,96 \\
0 & , \text { untuk } X_{5} \text { lainnya }\end{cases}
\end{aligned}
$$

$\hat{Y}_{i}=5,63-2,77 N_{4,3}\left(X_{5}\right)$

dengan

$N_{4,3}\left(X_{5}\right)$

$$
=\left\{\begin{array}{c}
\left(\frac{X_{5}-96,16}{13,8}\right)^{2}, 96,16 \leq X_{5}<109,96 \\
0, \text { untuk } X_{5} \text { lainnya }
\end{array}\right.
$$

Ketika persentase bernilai minimum yaitu 68,09\% dan disubstitusi ke persamaan (2.9) diperoleh jumlah balita penderita gizi buruk bertambah sebanyak 7 kasus. Apabila persentase maksimum yaitu 109,96\% disubstitusi ke persamaan (2.10) maka ditemukan kasus balita penderita gizi buruk berkurang sebanyak 3 kasus. Peningkatan 
persentase ibu hamil mendapat TTD akan menurunkan jumlah kasus balita penderita gizi buruk di Provinsi Bali.

6. Apabila variabel $X_{1}, X_{2}, X_{3}, X_{4}, X_{5}$ diasumsikan tetap, maka pengaruh persentase balita mendapat vitamin A $\left(X_{6}\right)$ terhadap jumlah balita penderita gizi buruk pada kecamatan ke- $i$ di Provinsi Bali $\left(Y_{i}\right)$ adalah sebagai berikut:

$\hat{Y}_{i}=5,63+1,91 N_{-2,3}\left(X_{6}\right)$

dengan

$N_{-2,3}\left(X_{6}\right)$

$$
= \begin{cases}\left(\frac{97,14-X_{6}}{2,66}\right)^{2}, & 94,48 \leq X_{6}<97,14 \\ 0 & , 97,14 \leq X_{6}<97,83 \\ 0 & , 97,83 \leq X_{6}<99,47 \\ 0 & , 99,47 \leq X_{6}<99,49 \\ 0 & , 99,49 \leq X_{6}<100 \\ 0 & , \text { untuk } X_{6} \text { lainnya }\end{cases}
$$

$\hat{Y}_{i}=5,63-0,66 N_{4,3}\left(X_{6}\right)$

dengan

$$
\begin{aligned}
& N_{4,3}\left(X_{6}\right) \\
& =\left\{\begin{array}{c}
\left(\frac{X_{6}-99,49}{0,51}\right)^{2}, 99,49 \leq X_{6}<100 \\
0, \text { untuk } X_{6} \text { lainnya }
\end{array}\right.
\end{aligned}
$$

Ketika persentase minimum yaitu 94,48\% dan disubstitusi ke persamaan (2.11) diperoleh jumlah balita penderita gizi buruk di kecamatan tersebut bertambah sebanyak 2 kasus. Sebaliknya, apabila persentase maksimum yaitu $100 \%$ disubstitusi ke persamaan (2.12) diperoleh kasus balita penderita gizi buruk berkurang sebanyak 1 kasus. Peningkatan persentase balita mendapat vitamin A akan menurunkan persentase jumlah kasus balita penderita gizi buruk di Provinsi Bali.

\section{SIMPULAN DAN SARAN}

Pemodelan kasus gizi buruk pada balita di Provinsi Bali dengan penerapan regresi nonparametrik truncated spline dan B-Spline menunjukkan bahwa regresi nonparametrik dengan basis $B$-Spline memiliki nilai GCV dan MSE yang paling minimum. Model kasus gizi buruk di Provinsi Bali dengan menggunakan regresi nonparametrik $B$-Spline kuadratik (orde 3) mampu menerangkan keragaman jumlah kasus gizi buruk pada balita pada 57 kecamatan di Provinsi Bali tahun 2018 sebesar 82,65\% , sisanya dipengaruhi oleh variabel lain di luar model.

Berdasarkan model yang diperoleh apabila persentase pemberian tablet tambah darah pada ibu hamil minimum maka jumlah kasus gizi buruk pada balita akan bertambah 7 kasus, sedangkan apabila persentase pemberian ASI Eksklusif maksimal maka jumlah kasus gizi buruk pada balita di Provinsi Bali akan berkurang sebanyak 9 kasus. Sehingga, dapat ditarik kesimpulan bahwa untuk mengurangi jumlah kasus gizi buruk di Provinsi Bali maka pemberian ASI Eksklusif oleh ibu haruslah dimaksimalkan dan pemberian tablet tambah darah pada ibu hamil juga harus dipantau karena pendistribusian tablet tambah darah melalui posyandu dan puskesmas merupakan salah satu upaya pemerintah dalam menjaga asupan ibu hamil.

Pada penelitian selanjutnya diharapkan dapat membandingkan regresi nonparametrik dengan basis spline lain seperti basis I-Spline, penalized spline, atau yang lain.

\section{DAFTAR PUSTAKA}

Anggreni, N. P. R., Suciptawati, N. L. P., \& Srinadi, I. G. A. M. (2018). Model Regresi Nonparametrik Spline Truncated Pada Jumlah Kasus Tuberkulosis di Provinsi Bali Tahun 2016. E-Jurnal Matematika, 7(3), 211.

https://doi.org/10.24843/mtk.2018.v07.i03. p205

Budiantara, I. N., Suryadi, F., Otok, B. W., \& Guritno, S. (2006). Pemodelan B-Spline Dan Mars Pada Nilai Ujian Masuk Terhadap Ipk Mahasiswa Jurusan Disain Komunikasi Visual Uk . Petra Surabaya. 8(1), 1-13.

Budiantara, I. N. (2011). Penelitian Bidang Regresi Spline Menuju Terwujudnya Penelitian Statistika yang Mandiri dan Berkarakter. Prosiding Seminar Nasional MIPA Undiksha 2011, 9-28. Diakses dari https://ejournal.undiksha.ac.id/index.php/se mnasmipa/issue/view/246

Dinas Kesehatan Provinsi Bali. (2016). Laporan Hasil Pemantauan Status gizi dan Pemantauan Konsumsi Gizi (PSG-PKG) Provinsi Bali 2016. Denpasar : Dinas Kesehatan Provinsi Bali 
(2017). Laporan Hasil Pemantauan Status gizi dan Pemantauan Konsumsi Gizi (PSG-PKG) Provinsi Bali 2017. Denpasar : Dinas Kesehatan Provinsi Bali

Eubank, R. L. (1999). Nonparametric Regression and Spline Smoothing 2nd Edition. Marcel Deker, Inc.

Lyche, T., \& Mørken, K. (2008). SplineMethods Draft. Department of Informatics, Center of Mathematics for Applications, University of Oslo.

Rahmawati, A. S., Ispriyanti, D., \& Warsito, B. (2017). Pemodelan Kasus Kemiskinan Di Jawa Tengah Menggunakan Regresi Nonparametrik Metode B-spline. Jurnal Gaussian, 6(1), 11-20. 